\title{
Molecular identification and first report of mitochondrial $C O I$ gene haplotypes in the hawksbill turtle Eretmochelys imbricata (Testudines: Cheloniidae) in the Colombian Caribbean nesting colonies
}

\author{
L. Daza-Criado and J. Hernández-Fernández \\ Laboratory of Molecular Biology and Genetics, \\ Genetics, Molecular Biology and Bioinformatics GENBIMOL, \\ Department of Natural Sciences and Environmental, \\ Faculty of Sciences and Engineering, Jorge Tadeo Lozano University, \\ Bogotá, Colombia \\ Corresponding author: J. Hernández-Fernández \\ E-mail: javier.hernandez@utadeo.edu.co
}

Genet. Mol. Res. 13 (3): 7123-7132 (2014)

Received June 24, 2013

Accepted December 11, 2013

Published February 21, 2014

DOI http://dx.doi.org/10.4238/2014.February.21.14

\begin{abstract}
Hawksbill sea turtles Eretmochelys imbricata are found extensively around the world, including the Atlantic, Pacific, and Indian Oceans; the Persian Gulf, and the Red and Mediterranean Seas. Populations of this species are affected by international trafficking of their shields, meat, and eggs, making it a critically endangered animal. We determined the haplotypes of 17 hawksbill foraging turtles of Islas del Rosario (Bolivar) and of the nesting beach Don Diego (Magdalena) in the Colombian Caribbean based on amplification and sequencing of the mitochondrial gene cytochrome oxidase c subunit I (COI). We identified 5 haplotypes, including EI-A1 previously reported in Puerto Rico, which was similar to 10 of the study samples. To our knowledge,
\end{abstract}


the remaining 4 haplotypes have not been described. Samples EICOI11 and EICOI 3 showed $0.2 \%$ divergence from EI-A1, by a single nucleotide change, and were classified as the EI-A2 haplotype. EICOI6, EICOI14, and EICOI12 samples showed $0.2 \%$ divergence from EI-A1 and $0.3 \%$ divergence from EI-A2 and were classified as EI-A3 haplotype. Samples EICOI16 and EICOI15 presented 5 nucleotide changes each and were classified as 2 different haplotypes, EI-A4 and EI-A5, respectively. The last 2 haplotypes had higher nucleotide diversity $(\mathrm{K} 2 \mathrm{P}=1.7 \%)$ than that by the first 3 haplotypes. EI-A1 and EI-A2 occurred in nesting individuals, and EI-A2, EI-A3, EI-A4, and EI-A5 occurred in foraging individuals. The description of the haplotypes may be associated with reproductive migrations or foraging and could support the hypothesis of natal homing. Furthermore, they can be used in phylogeographic studies.

Key words: Cytochrome oxidase c subunit I (COI) nucleotide change; Sequences; Natal homing; Eretmochelys imbricata

\section{INTRODUCTION}

The hawksbill turtle Eretmochelys imbricata (Linnaeus, 1776) presents a complex and specialized lifestyle. Sexual maturity is reached between 20 and 30 years of age (Bowen and Karl, 2007), and this requires sandy beaches, which are often in the proximity of coral reefs, coasts, and estuaries (Cuevas et al., 2008). Hawksbill turtles travel long distances, often thousands of kilometers, moving offshore as well as to different countries' territorial waters (Chacón, 2004).

The hawksbill turtle has been classified as critically endangered by the International Union for Conservation of Nature (Unión Internacional para la Conservación de la Naturaleza, 2010). It is at risk of extinction because people collect their eggs and use their shells for decorative purposes (jewelry and other luxury items) (Castaño-Mora, 2002). As a result, the Convention on International Trade in Endangered Species of Wild Fauna and Flora declared the trade of these shells illegal. However, the demand for shells continues today on the black market, especially in Japan (Bass, 1999). This illegal trade has generated a dramatic decrease in their populations (Meylan, 1999). For these reasons, the hawksbill turtle conservation is a priority at the national and global level (Trujillo, 2009).

The Barcode of Life Project (DNA barcoding) is a worldwide initiative devoted to undertaking a molecular inventory of Earth's biodiversity (Vargas et al., 2009). In recent years, it has become one of the most important international programs for the molecular identification of many species (Hebert et al., 2004; Hebert and Gregory, 2005; Smith et al., 2005). This project proposes using a 648-bp cytochrome oxidase c subunit I (COI) gene fragment of the mitochondrial DNA (mtDNA) as a molecular label to identify species (Hebert et al., 2003a). The Barcode of Life Project has reported around 1,723,547 barcodes, describing 115,124 animal species (www.boldsystems.org). DNA barcoding of threatened species provides an identification system for these species or their parts, which makes efficient classification possible and provides an alternative method to develop appropriate conservation strategies (DeSalle and Amato, 2004). It is also useful in conservation biology, as a method to conduct a biodiversity census, and when traditional methods are ineffective, such as the identification of eggs and larval forms, and in the 
analysis of stomach contents or excreta to determine food webs (Stoeckle, 2003). Furthermore, this method can be potentially employed in forensic cases to identify tissue samples that were obtained from illegal commerce or use of eggs and meat (Hajibabaei et al., 2006). The DNA barcodes are also applicable in the research field to identify a lost turtle's nest and stranded turtles on the beaches that are often found in an advanced state of decomposition, which complicates the correct identification of species. Another possibility is the rapid identification of interspecific hybrids, which can be as frequent as $45 \%$ of the population of hawksbill turtles in Bahia, Brazil.

The use of genetic markers that are inherited through the maternal line (mtDNA) shows strong population structure between nesting colonies (Bowen et al., 2005), meaning that the genetic composition of females in the reproductive age is given by the presence of a specific haplotype. In sea turtles, mitochondrial haplotypes (mtDNA), which have been very useful in identifying nesting colonies and their relation to foraging areas, are defined by one or more single nucleotide polymorphisms. Therefore, this method has been useful in the global phylogeography of sea turtles because it helped to generate the first hypothesis about their evolutionary history, biogeography, and migration patterns (Bowen et al., 1993, 2005). With this background, our study identified and reported for the first time the haplotypes of 17 individuals of the hawksbill sea turtle, E. imbricata, from Colombian Caribbean nesting colonies using the mitochondrial COI gene as a molecular marker.

\section{MATERIAL AND METHODS}

We obtained 14 samples of peripheral blood from foraging hawksbill turtles, E. imbricata, from Islas del Rosario (Bolivar) and 3 samples from nesting turtles of Don Diego beach (Magdalena) (Table 1). These 17 individuals currently are part of a project of increasing in captivity (headstarting) in the Colombian Caribbean. The samples were obtained from blood tissue at the level of the dorsal civic breasts of E. imbricata individuals, using a previously published method (Dutton, 1996) and stored in sterile tubes containing 0.1 M Tris-ethylenediaminetetraacetic acid at $4{ }^{\circ} \mathrm{C}$ for further analysis in the Laboratory of Molecular Biology at the University Jorge Tadeo Lozano in Bogota.

\begin{tabular}{|c|c|c|c|c|c|c|c|c|}
\hline Provenance & Code & Sex & Maturity & Blood volume $(\mathrm{mL})$ & $\operatorname{LCC}(\mathrm{cm})$ & $\mathrm{ACC}(\mathrm{cm})$ & $\mathrm{LC}(\mathrm{cm})$ & $\mathrm{AC}(\mathrm{cm})$ \\
\hline Santa Marta & EICOI1 & Und. & Juvenile & 4 & - & - & - & - \\
\hline Santa Marta & EICOI 2 & Female & Adult & 8 & 70 & 63 & 25 & 15 \\
\hline Santa Marta & EICOI 3 & Female & Adult & 8 & 68 & 62 & 16 & 12 \\
\hline CEINER & EICOI 4 & Male & Juvenile & 8 & 52 & 48 & 12 & 8 \\
\hline CEINER & EICOI 5 & Male & Adult & 8 & 66 & 59 & 17 & 10 \\
\hline CEINER & EICOI 6 & Male & Juvenile & 8 & 61 & 54 & 13 & 9 \\
\hline CEINER & EICOI 7 & Male & Juvenile & 4 & 60 & 55 & 12 & 7 \\
\hline CEINER & EICOI 8 & Und. & Juvenile & 4 & 56 & 50 & 11 & 8 \\
\hline CEINER & EICOI 9 & Und. & Juvenile & 8 & 62 & 57 & 13 & 9 \\
\hline CEINER & EICOI 10 & Und. & Juvenile & 2.5 & 53 & 46 & 10.5 & 6 \\
\hline CEINER & EICOI 11 & Und. & Juvenile & 5 & 56 & 48 & 11.5 & 9 \\
\hline CEINER & EICOI 12 & Und. & Juvenile & 8 & 53 & 50 & 10.5 & 7 \\
\hline CEINER & EICOI 13 & Female & Adult & 8 & 71 & 63 & 14 & 12 \\
\hline CEINER & EICOI 14 & Male & Adult & 4 & 79 & 63 & 15 & 12 \\
\hline CEINER & EICOI 15 & Und. & Juvenile & 8 & 58 & 49 & 11.4 & 9 \\
\hline CEINER & EICOI 16 & Und. & Juvenile & 8 & 60 & 53 & 11.6 & 8.5 \\
\hline CEINER & EICOI 17 & Male & Adult & 8 & 61 & 64 & 12 & 7.5 \\
\hline
\end{tabular}

Santa Marta = Sea Aquarium and Museum Rodadero; CEINER = Oceanário CEINER Isla San Martin de Pajarales PNNCRSB; Und. = undetermined. 
The DNA extraction was performed using the Tissue GF-1 DNA Extraction kit (Vivantis, Malaysia) following the manufacturer protocol, and the DNA was electrophoresed on a $1 \%$ agarose gel with ethidium bromide incorporated on the gel.

The amplification of the mitochondrial COI gene was performed using heterologous primers VF2 and VR1, which were published previously (Ward et al., 2005; Ivanova et al., 2007) and designed to amplify the COI gene in turtle Chelonia mydas. The polymerase chain reaction (PCR) was performed in a $25-\mathrm{mL}$ reaction containing 50-100 $\mathrm{ng}$ DNA, $1 X$ PCR buffer (50 mM KCl and $10 \mathrm{mM}$ Tris-HCl, $\mathrm{pH} 8.3$ ), $2 \mathrm{mM} \mathrm{MgCl}_{2}, 0.5 \mathrm{mM}$ of each primer, $200 \mathrm{mM}$ of each dNTP, and $1 \mathrm{U}$ Taq polymerase (Bioline Inc., USA). The following amplification conditions were used: initial denaturing for $5 \mathrm{~min}$ at $94^{\circ} \mathrm{C} ; 35$ cycles of $94^{\circ} \mathrm{C}$ for $1 \mathrm{~min}, 1 \mathrm{~min}$ at $52^{\circ} \mathrm{C}$, and $72^{\circ} \mathrm{C}$ for $1 \mathrm{~min}$; and a final extension step for 10 min at $72^{\circ} \mathrm{C}$. Automated sequencing was performed in an ABI3730XL sequencer. The sequences were assembled with the program CLC DNA WorkBench 5.6.1 (CLC Bio, Denmark), and the DNA sequences were compared at level of gender and species with the basic local alignment search tool (BLAST) (http://blast.ncbi.nlm.nih.gov/).

The sequences that were obtained in this study, as well as the described sequences of the COI gene in sea turtles in the BOLD-Systems and GenBank databases (Table 2), were aligned with the program BioEdit Sequence Alignment Editor 7.0 (Hall, 1999) and ClustalW (European Bioinformatics Institute, UK) to analyze variable positions and nucleotide changes between the sequences.

\begin{tabular}{|c|c|c|c|c|}
\hline Species & Unit taxonomic & Geographic location & GenBank accession No. & Author \\
\hline Chelonia mydas & $\mathrm{Cm}$ & USA & $\begin{array}{l}\text { GQ152880 } \\
\text { GQ152881 } \\
\text { GQ152882 }\end{array}$ & Naro-Maciel et al., 2010 \\
\hline Dermochelys coriacea & Dc & Australia & GQ152876 & \\
\hline Eretmochelys imbricata & $\mathrm{Ei}$ & Puerto Rico & $\begin{array}{l}\text { GQ152885 } \\
\text { GQ152886 } \\
\text { GQ152887 }\end{array}$ & \\
\hline Lepidochelys kempii & Lk & USA & GQ152891 & \\
\hline Lepidochelys olivacea & Lo & Australia & GQ152890 & \\
\hline Natator depressa & $\mathrm{Nd}$ & Australia & GQ152883 GQ152884 & \\
\hline Caretta caretta & $\mathrm{Cc}$ & USA & GQ152888GQ152889 & \\
\hline Trachemys scripta & Ts & China & JF700194 & Zhang et al., 2011 \\
\hline
\end{tabular}

To generate the barcode of E. imbricata, a taxonomic identification motor of BOLD Systems (http://www.boldsystems.org/views/idrequest.php), which aligned the sequences and calculated the degree of divergence between the sequences using the 2-parameter mean distance model of Kimura (K2P) (Kimura, 1980) generated the dendrogram. Furthermore, the results were confirmed by neighbor-joining analysis using the MEGA 4.0 software (Tamura et al., 2007) with bootstrap values from 1000 permutations, with which it was also possible to determine the haplotypes that were found.

\section{RESULTS}

Seventeen COI gene fragments of 611 bp were amplified by PCR and sequenced, 
revealing a maximum identity between 98 and $100 \%$ with $E$. imbricata through BLAST analysis. The nucleotide barcode was generated with this label for each individual and was submitted as accession numbers TMCI002 to TMCI018 in BOLD Systems and JX571752 to JX571768 in GenBank.

The nucleotide similarity between individual hawksbill turtles (intraspecific relationship) was about $99.7 \%$. Nucleotide differences were below $2 \%(\mathrm{~K} 2 \mathrm{P}=0.3 \%)$ and identified 5 haplotypes (Table 3). The haplotype EI-A1, which was described previously in Puerto Rico (Accession GQ152887), showed 100\% identity with study samples EICOI1, EICOI2, EICOI4, EICOI5, EICOI7, EICOI8, EICOI9, EICOI10, EICOI17, and EICOI13. The other 4 haplotypes were not previously described. Samples EICOI3 and EICOI11 showed a divergence from EI-A1 of $0.2 \%$, which was represented by a nucleotide change; therefore, they were classified as the EI-A2 haplotype (Table 3). EICOI6, EICOI12, and EICOI14 showed $0.2 \%$ divergence from EI-A1 and $0.3 \%$ divergence from EI-A2 and were classified as the EI-A3 haplotype (Table 3). The EICOI15 sample showed 5 nucleotide changes and was classified as the EI-A4 haplotype (Table 3). Finally, the sample EICOI16 showed 5 nucleotide changes and was classified as the EI-A5 haplotype.

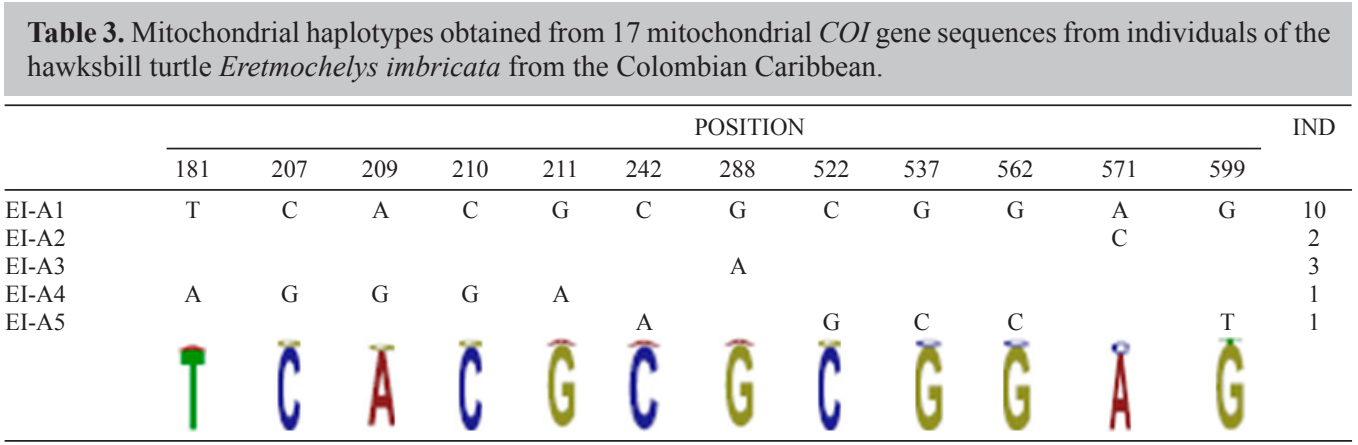

$\mathrm{IND}=$ number of individuals with each haplotype.

Haplotypes EI-A4 and EI-A5 showed the highest nucleotide diversity $(\mathrm{K} 2 \mathrm{P}=1.7 \%)$ of the identified haplotypes. These differences are represented by 5 nucleotide changes in each haplotype relative to the reference haplotype EI-A1 in sites 181, 207, 209, 210, and 211 of the EI-A4 haplotype, and in sites 242, 522, 537, 562, and 599 of the EI-A5 haplotype (Table 3). Haplotypes EI-A1 and EI-A2 were registered in nesting turtles and haplotypes EI-A2, EI-A3, EI-A4, and EI-A5 were observed in foraging turtles.

The nucleotide divergence matrix (Table 4) that was established between turtles in this study and the sequences that were described in GenBank (Table 2) showed high nucleotide divergence, which occurs between hawksbills and other sea turtles of the Cheloniidae family, with divergence values between 7\% for Lepidochelys and 9\% for Caretta and Natator, which are accepted values to distinguish individuals at the genetic level (Hebert et al., 2003b; Lanteri, 2007). The sea turtle Dermochelys coriacea from the Dermochelyidae family showed a divergence of 9.2\%, and the tortoise Trachemys scripta showed a divergence of $14.9 \%$, which correspond to divergence values that are established for families (Hebert et al., 2003b; Lanteri, 2007). 


\begin{tabular}{|c|c|c|c|c|c|c|c|c|c|c|c|c|c|c|}
\hline & 1 & 2 & 3 & 4 & 5 & 6 & 7 & 8 & 9 & 10 & 11 & 12 & 13 & 14 \\
\hline \multicolumn{15}{|l|}{ EICOI } \\
\hline EIGQ87 & 0.000 & & & & & & & & & & & & & \\
\hline EIGQ86 & 0.013 & 0.013 & & & & & & & & & & & & \\
\hline EIGQ85 & 0.017 & 0.017 & 0.007 & & & & & & & & & & & \\
\hline LKGQ91 & 0.070 & 0.070 & 0.071 & 0.079 & & & & & & & & & & \\
\hline LOGQ90 & 0.073 & 0.073 & 0.075 & 0.083 & 0.020 & & & & & & & & & \\
\hline CCGQ89 & 0.079 & 0.079 & 0.083 & 0.088 & 0.048 & 0.057 & & & & & & & & \\
\hline CMGQ82 & 0.084 & 0.084 & 0.086 & 0.079 & 0.091 & 0.083 & 0.092 & & & & & & & \\
\hline CMGQ81 & 0.084 & 0.084 & 0.086 & 0.079 & 0.091 & 0.083 & 0.092 & 0.000 & & & & & & \\
\hline 0. CMGQ80 & 0.084 & 0.084 & 0.086 & 0.079 & 0.089 & 0.085 & 0.096 & 0.012 & 0.012 & & & & & \\
\hline 1. NDGQ83 & 0.090 & 0.090 & 0.086 & 0.096 & 0.090 & 0.092 & 0.079 & 0.070 & 0.070 & 0.077 & & & & \\
\hline 2. NDGQ84 & 0.090 & 0.090 & 0.096 & 0.096 & 0.090 & 0.092 & 0.079 & 0.070 & 0.070 & 0.077 & 0.000 & & & \\
\hline 3. CCGQ88 & 0.090 & 0.090 & 0.092 & 0.092 & 0.059 & 0.068 & 0.013 & 0.096 & 0.096 & 0.100 & 0.088 & 0.088 & & \\
\hline 4. DCGQ76 & 0.092 & 0.092 & 0.098 & 0.098 & 0.092 & 0.094 & 0.081 & 0.072 & 0.072 & 0.079 & 0.002 & 0.002 & 0.090 & \\
\hline 5. TSGQ94 & 0.149 & 0.149 & 0.162 & 0.162 & 0.144 & 0.154 & 0.154 & 0.165 & 0.165 & 0.167 & 0.172 & 0.172 & 0.152 & 0.174 \\
\hline
\end{tabular}

EICOI = study consensus sequence $E$. imbricata . GenBank sequences; EIGQ = E. imbricata ;MGQ = Chelonia mydas; $\mathrm{NDGQ}=$ Natator depressus $; \mathrm{LKGQ}=$ Lepidochelys kempii $; \mathrm{LOGQ}=$ L. olivacea $; \mathrm{CCGQ}=$ Caretta caretta; DCGQ = Dermochelys coriacea $; \mathrm{TSGQ}=$ Trachemys scripta .

The neighbor-joining analysis revealed the presence of 3 clades, which were designated clades A, B, and C (Figure 1). Clade A identifies the hawksbill turtle in this study, which was grouped with previously described sequences in GenBank and supported with $99 \%$ significance. Clade B has a relationship of $84 \%$ with the genera Chelonia, Natator, and Dermochelys. Clade $\mathrm{C}$ groups the genera Lepidochelys and Caretta with $73 \%$ similarity. We used the tortoise T. scripta as the outgroup in a separate clade, showing the nucleotide and morphological divergence that occurs between families of the same order.

\section{DISCUSSION}

The proposed identification method using the mitochondrial COI gene (Hebert et al., 2004) was used to identify 17 hawksbill turtles that were reported in the BOLD Systems database for documentation support of biodiversity through the Barcode of Life Project. This application is of great importance to assess, facilitate, and complement the taxonomic study. Hence, it contributes to the conservation of hawksbill turtles. Constantly, humans take advantage of turtles to use their meat, shells, and eggs. It is difficult to correctly identify these parts of the turtles (Chacón, 2004); for that reason, the use of the standardized method, or variations for DNA of different tissues, could be a tool that reveals the depredation of hawksbill turtles. With this contribution, campaigns that promote the conservation of not only hawksbill turtles but also ecosystems and nesting beaches can be organized. The proposed method can also be used for field work in the identification of lost nests, beached animals, dead animals as part of the incidental capture in fishing nets, and forensic confrontation when the turtle eggs or meat are the only available material.

The K2P that was obtained for the 17 COI sequences in the study showed a $0.3 \%$ divergence, which identifies $E$. imbricata at the intraspecific level according to the established values of genetic divergence (Hebert et al., 2003b; Lanteri, 2007).

Research on population genetic structure of nesting hawksbills showed a high struc- 


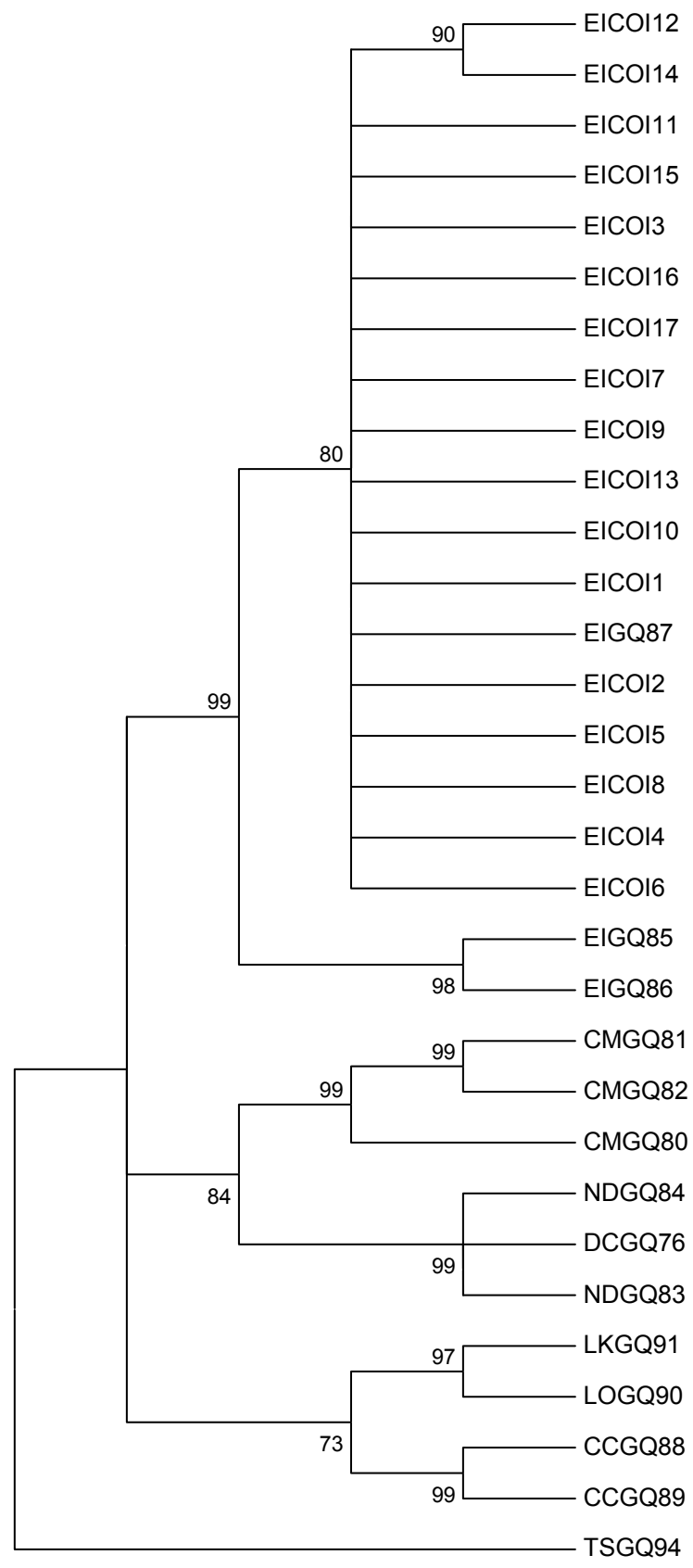

Figure 1. Neighbor-joining tree of 17 mitochondrial COI gene sequences obtained of hawksbill turtles and the terrestrial turtle Trachemys scripta reported in GenBank. Values of 1000 replicas of the "bootstrap" are represented on the branches. EICOI1-EICOI17: study samples Eretmochelys imbricata. GenBank sequences: EIGQ: E. imbricata, CMGQ: Chelonia mydas, NDGQ: Natator depressus, LKGQ: Lepidochelys kempii, LOGQ: L. olivacea, CCGQ: Caretta caretta, DCGQ: Dermochelys coriacea, TSGQ: T. scripta. 
ture, which means that the variations of the haplotype frequencies of the control region, or D-loop of mtDNA among nesting colonies of the same beach, is very low or nonexistent (Limpus et al., 1983, Bowen et al., 1993, Broderick et al., 1994; Encalada et al., 1998; Maffucci et al., 2006), a fact which supports the hypothesis of natal homing (Bowen and Karl, 2007). This study identified 5 different haplotypes (Table 3) of the hawksbill turtle populations and found that 4 of these represent the first contribution to the Colombian Caribbean and were represented in 7 individuals. This may be due to the frequent visits of females to feeding areas and conditions on this beach that are favorable for nesting (Ceballos-Fonseca, 2000). The Don Diego beach (Magdalena) maintains conditions that are suitable for nesting turtles. Additionally, it nesting has historically been high, particularly for hawksbills (E. imbricata), Caretta caretta, and green turtles (Chelonia mydas) (Ministerio de Medio Ambiente y Desarrollo Territorial, 2002).

Genetic studies (mtDNA) in populations of E. imbricata were carried out in the Caribbean region using the haplotype frequencies of nesting colonies as natural genetic markers to determine the source of the populations in foraging areas. Although these turtles came from different nesting places, this analysis revealed a high frequency of the EI-A1 haplotype (10 individuals) in foraging areas, which indicated that this colony may be part of the population that was described in Puerto Rico by Naro-Maciel et al. (2010), and lower haplotype frequencies of EI-A2, EI-A3, EI-A4, and EI-A5. These haplotypes were the first to be reported in the Colombian Caribbean hawksbill using the $\mathrm{COI}$ gene as a marker.

The neighbor-joining tree allowed us to verify the identification of hawksbill turtles by the number of changes or nucleotide substitutions that were found between sequences relative to reported samples in GenBank (Table 2). It showed 99\% homology by using 1000 bootstrap replicates with a high probability (over $80 \%$ ) for the separation of species that are clearly differentiated by morphological traits (Page and Holmes, 1998; Peña, 2011). Neighbor-joining trees are often used in molecular barcode (DNA barcoding) studies (Hebert et al., 2004), in which a 648-bp segment of the mitochondrial $C O I$ gene is used as a unique identifier for each species of the animal kingdom (Hebert et al., 2003a,b, 2004, 2010). This was corroborated by the identification of the $\mathrm{COI}$ gene sequence from the hawksbill turtle Carey, and a dendrogram was generated that grouped the nucleotide sequences that have greater similarity (Figure 1). For DNA sequences, the genetic distance between 2 terminals is calculated according to the total number of substitutions of nitrogenous bases (Saitou and Nei, 1987). To build the tree, the neighbor-joining method was used as internal information values of the K2P distance matrix K2P (Table 4). Therefore, the neighbor-joining values reflect the degree of similarity between the terminals. The divergence between hawksbill individuals and other species of the families Cheloniidae, Dermochelys, and tortoises represented by $T$. scripta was confirmed by species being displayed as separate groups (Figure 1).

This study showed that DNA barcodes that are generated by the COI gene are a valuable molecular tool that allows discrimination of hawksbill turtles at the intraspecific level. In addition, DNA barcodes indicated that each haplotype group of individuals was derived from the same maternal line of hawksbill turtles. The presence of these haplotypes may be associated with reproductive migration, foraging, and development (natal homing) that can be used in phylogeographic studies. The high genetic variability that was presented in populations in this area revealed that Colombian Caribbean beaches have essential conditions for nesting hawksbill turtles. 


\section{ACKNOWLEDGMENTS}

We are grateful to CEINER Oceanarium on the island of St. Martin Pajarales and Aquarium and Maritime Museum in Santa Marta Rodadero for collaboration in obtaining and providing samples of hawksbill turtles, Eretmochelys imbricata, for the development of this study. Samples were obtained under a research permit that was granted by the Ministry of Environment and Territorial Development (\#24 of June 22, 2012) and Contract for Access to Genetic Resources (\#64 of April 23, 2013).

\section{REFERENCES}

Bass AL (1999). Genetic analysis to elucidate the natural history and behavior of hawksbill turtles (Eretmochelys imbricata) in the wider Caribbean: a review and re-analysis. Chelonian Conserv. Biol. 3: 195-199.

Bowen BW and Karl SA (2007). Population genetics and phylogeography of sea turtles. Mol. Ecol. 16: 4886-4907.

Bowen BW, Avise JC, Richardson JI, Meylan AB, et al. (1993). Population structure of loggerhead turtles (Caretta caretta) in the northwestern Atlantic Ocean and Mediterranean Sea. Conserv. Biol. 7: 834-844.

Bowen BW, Bass AL, Soares L and Toonen RJ (2005). Conservation implications of complex population structure: lessons from the loggerhead turtle (Caretta caretta). Mol. Ecol. 14: 2389-2402.

Broderick D, Moritz C, Miller JD, Guinea M, et al. (1994). Genetic studies of the hawksbill turtle: evidence for multiple stocks and mixed feeding grounds in Australian waters. Pac. Conserv. Biol. 1: 123-131.

Castaño-Mora OV (2002). Libro Rojo de Reptiles de Colombia. Instituto de Ciencias Naturales, Universidad Nacional de Colombia, Ministerio del Medio Ambiente, Conservación Internacional, Bogotá

Ceballos-Fonseca C (2004). Distribución de playas de anidación y áreas de alimentación de tortugas marinas y sus amenazas en el Caribe Colombiano. Bol. Invest. Mar. Cost. 33: 79-99.

Chacón D (2004). La tortuga carey del Caribe: Introducción a su biología y estado de conservación. Available at [www. hawksbillwwf.org]. WWF-Programa Regional Para América Latina y El Caribe, San José, Costa Rica, 38. Accessed July 20, 2013.

Cuevas E, Abreu-Grobois FA, Guzmán-Hernández V, Liceaga-Correa MA, et al. (2008). Post-nesting migratory movements of hawksbill turtles Eretmochelys imbricata in waters adjacent to the Yucatan Peninsula, Mexico. Endangered Species Res. 10: 123-133.

DeSalle R and Amato G (2004). The expansion of conservation genetics. Nat. Rev. Genet. 5: 702-712.

Dutton PH (1996). Methods for Collection and Preservation of Samples for Sea Turtle Genetic Studies. In: Proceedings of the International Symposium on Sea Turtle Conservation Genetics (Bowen BW and Witzell WN, eds.). NOAA Technical Memorandum, Miami, 17-24.

Encalada SE, Bjorndal KA, Bolten AB, Zurita JC, et al. (1998). Population structure of loggerhead turtle (Caretta caretta) nesting colonies in the Atlantic and Mediterranean as inferred from mitochondrial DNA control region sequences. Mar. Biol. 130: 567-575.

Hajibabaei M, Smith MA, Janzen DH, Rodriguez JJ, et al. (2006). A minimalist barcode can identify a specimen whose DNA is degraded. Mol. Ecol. Notes 6: 959-964.

Hall TA (1999). BioEdit: a user-friendly biological sequence alignment editor and analysis program for Windows 95/98/ NT. Nucleic Acids Symp. Series 41: 95-98.

Hebert PC, MacDonald N, Flegel K and Stanbrook MB (2010). Competing interests and undergraduate medical education: time for transparency. Can. Med. Assoc. J. 182: 1279-1279.

Hebert PD and Gregory TR (2005). The promise of DNA barcoding for taxonomy. Syst. Biol. 54: 852-859.

Hebert PD, Cywinska A, Ball SL and deWaard JR (2003a). Biological identifications through DNA barcodes. Proc. Biol. Sci. 270: 313-321.

Hebert PD, Ratnasingham S and deWaard JR (2003b). Barcoding animal life: cytochrome c oxidase subunit 1 divergences among closely related species. Proc. Biol. Sci. 270 (Suppl 1): S96-S99.

Hebert PD, Penton EH, Burns JM, Janzen DH, et al. (2004). Ten species in one: DNA barcoding reveals cryptic species in the Neotropical skipper butterfly Astraptes fulgerator. Proc. Natl. Acad. Sci. U. S. A. 101: 14812-14817.

Ivanova N, Zemlak T, Hanner R and Hebert P (2007). Universal primer cocktails for fish DNA barcoding. Mol. Ecol. Notes 7: 544-548.

Kimura M (1980). A simple method for estimating evolutionary rates of base substitutions through comparative studies of 
nucleotide sequences. J. Mol. Evol. 16: 111-120.

Lanteri AA (2007). Código de barras del ADN y sus posibles aplicaciones en el campo de la entomología. Rev. Soc. Entomol. Argent. 66: 15-25.

Limpus CJ, Miller JD, Baker V and McLachlan E (1983). The hawksbill turtle, Eretmochelys imbricata (L.), in northeastern Australia: the Campbell Island rookery. Aust. Wildlife Res. 10: 185-197.

Maffucci F, Kooistra WHCF and Bentivegna F (2006). Natal origin of loggerhead turtles, Caretta caretta, in the neritic habitat off the Italian coasts, Central Mediterranean. Biol. Conserv. 127: 183-189.

Meylan AB (1999). Status of the hawksbill turtle (Eretmochelys imbricata) in the Caribbean region. Chelonian Conserv. Biol. 3: 177-184.

Ministerio de Medio Ambiente y Desarrollo Territorial (2002). Programa Nacional para la Conservación de las Tortugas Marinas y Continentales en Colombia. Ministerio del Medio Ambiente, Bogotá.

Naro-Maciel E, Reid B, Fitzsimmons NN, Le M, et al. (2010). DNA barcodes for globally threatened marine turtles: a registry approach to documenting biodiversity. Mol. Ecol. Resour. 10: 252-263.

Page M and Holmes C (1998). Molecular Evolution. A Phylogenetic Approach. Blackwell Scientific, Oxford.

Peña C (2011). Métodos de inferencia filogenética. Rev. Peruana Biol. 18: 265-267.

Saitou N and Nei M (1987). The neighbor-joining method: a new method for reconstructing phylogenetic trees. Mol. Biol. Evol. 4: 406-425.

Smith MA, Fisher BL and Hebert PD (2005). DNA barcoding for effective biodiversity assessment of a hyperdiverse arthropod group: the ants of Madagascar. Philos. Trans. R. Soc. Lond. B Biol. Sci. 360: 1825-1834.

Stoeckle M (2003). Taxonomy, DNA, and the bar code of life. Bioscience 53: 796-797.

Tamura K, Dudley J, Nei M and Kumar S (2007). MEGA4: Molecular Evolutionary Genetics Analysis (MEGA) software version 4.0. Mol. Biol. Evol. 24: 1596-1599.

Trujillo N (2009). Caracterización genética de la tortuga carey (Eretmochelys imbricata (Linneaus, 1766)) en Colombia, basada en la región control de ADNmt. Universidad del Quindío, Armenia.

Unión Internacional para la Conservación de la Naturaleza (IUCN) (2010). IUCN Red List of Threatened Species. Version 2010.1. Available at [www.iucnredlist.org]. Accessed January 25, 2012.

Vargas SM, Araujo FC and Santos FR (2009). DNA barcoding of Brazilian sea turtles (Testudines). Genet. Mol. Biol. 32: 608-612.

Ward RD, Zemlak TS, Innes BH, Last PR, et al. (2005). DNA barcoding Australia's fish species. Philos. Trans. R. Soc. Lond. B Biol. Sci. 360: 1847-1857.

Zhang H, Chen SL, Cu LN and Yao H (2011). Trachemys scripta voucher AS62MT01 cytochrome oxidase subunit I (COI) gene, partial cds; mitochondrial. Accesion number JF700194, published in GENBANK. Available at [http:// www.ncbi.nlm.nih.gov/]. Accessed July 10, 2013. 